\title{
EKONOMICZNE PODSTAWY PRAWA POMOCY PUBLICZNEJ
}

\section{WSTĘP}

Konkurencja na rynku może zostać naruszona poprzez działanie przedsiębiorców albo przez działanie państwa. Antykonkurencyjnej aktywności przedsiębiorców ma przeciwdziałać prawo antymonopolowe, a antykonkurencyjną aktywność władz publicznych ma ograniczać prawo pomocy publicznej ${ }^{1}$. O ile jednak zakaz antykonkurencyjnych działań przedsiębiorców doznaje bardzo niewielu wyjątków ${ }^{2}$, o tyle w przypadku działań władz publicznych dopuszczalność interwencji państwa wciąż pozostaje dość rozbudowana. Pomimo formalnego zakazu udzielania pomocy publicznej, zawartego w art. 107 Traktatu o funkcjonowaniu Unii Europejskiej $^{3}$ (dalej jako „Traktat” lub „TFUE”), pomoc taka jest udzielana, stanowiąc, w niektórych wypadkach, jeden z kluczowych elementów polityki gospodarczej, i to nawet w państwach o bardzo rozwiniętej gospodarce wolnorynkowej ${ }^{4}$. Interwencja władz publicznych na rynku jest zresztą wspólną cechą

${ }^{1} \mathrm{~W}$ literaturze przedmiotu możemy spotkać się z określeniami „prawo pomocy publicznej” lub „prawo pomocy państwa”. Mimo możliwych różnic znaczeniowych tych dwóch pojęć, które zresztą nie są duże, w pracy tej są one używane zamiennie.

${ }^{2} \mathrm{Na}$ ten temat zob. T. Skoczny, Instrumenty relatywizacji i racjonalizacji zakazów praktyk ograniczających konkurencje, [w:] Granice wolności gospodarczej w systemie spotecznej gospodarki rynkowej. Ksiega jubileuszowa zokazji 40-lecia pracy naukowejprof. dr. hab. Jana Grabowskiego, GWSH, Katowice 2004, s. 247 i n.

${ }^{3}$ Traktat o funkcjonowaniu Unii Europejskiej (wersja skonsolidowana), Dz. U. WE C 115 z 9 maja 2008 r., s. 47 i n. W tekście przyjęto już nową numerację przepisów Traktatu, jednakże starsze akty wykonawcze zawierają odniesienia do starej numeracji sprzed wejścia w życie Traktatu z Lizbony.

${ }^{4}$ F. G. Jacobs, [w:] A. Biondi, P. Eeckhout, J. Flynn (red.), The Law of State Aid in the European Union, Oxford University Press, Oxford 2005, s. VII. 
współczesnych państw i może przybierać różne formy, realizować wiele zadań oraz przynosić zróżnicowane skutki ${ }^{5}$.

W dotychczasowym dyskursie prawniczym i ekonomicznym podstawom prawa pomocy publicznej nie poświęcano zbyt wiele miejsca. Biorąc to pod uwagę, warto zastanowić się nad zwiększającą się rolą ekonomicznej analizy w prawie pomocy publicznej. W tym zakresie prawo to może przejść podobną ewolucję jak prawo antymonopolowe, z którego doświadczeń i ustaleń należałoby w trakcie tego rozwoju skorzystać ${ }^{6}$. Rozwój podejścia ekonomicznego w dziedzinie prawa pomocy publicznej przyczyni się do zwiększenia pewności prawnej i może przeobrazić się w „cichą rewolucję”, która zmieni oblicze tej gałęzi prawa publicznego $^{7}$. Choć wydaje się, że wobec kryzysu finansowego rewolucja ta może nadejść dopiero za kilka lat i w chwili obecnej możemy zaobserwować nawrót do protekcjonizmu i interwencjonizmu w poszczególnych krajach członkowskich UE, i to w skali niespotykanej od wielu lat, to jednak zmiany w podejściu do prawa pomocy są zauważalne. Należy bowiem zwrócić uwagę na fakt, że od 2005 r. odbywa się reforma wspólnotowych przepisów dotyczących pomocy publicznej określana zbiorczo jako State Aid Action Plan (dalej jako „SAAP”). Reforma ta, mająca swoje polityczne źródło w tzw. strategii lizbońskiej, ma w swoich założeniach przyczynić się do ukierunkowania pomocy publicznej na działania o charakterze horyzontalnym, w tym przede wszystkim służące wspieraniu innowacyjności, badań i rozwoju, stymulowaniu przedsiębiorczości, inwestowaniu w kapitał ludzki i ochronę środowiska. Swoje znaczenie ma zwiększyć także pomoc o charakterze regionalnym, która powinna przyczyniać się do zmniejszania dysproporcji w rozwoju pomiędzy regionami UE. Wynika $\mathrm{z}$ tego, że Komisja jest za odejściem od sektorowych form pomocy, realizując zasadę „mniej pomocy, ale za to lepiej ukierunkowanej".

$Z$ tych to powodów warto poddać analizie ekonomiczne podstawy prawa pomocy publicznej. W toku analizy pokazane zostaną podstawy prawne systemu pomocy publicznej w Unii Europejskiej i w Polsce oraz przedstawiona definicja pojęcia „pomocy publicznej”. Następnie ukazane zostaną rodzaje pomocy publicznej stanowiące wyjątki od generalnego zakazu udzielania pomocy publicznej.

${ }^{5}$ A. Knaul, F. Perez Flores, State Aid, [w:] J. Faull i A. Nikpay (red.), The EC law of competition, Oxford University Press, Oxford 2007, s. 1705.

${ }^{6}$ C. Ahlborn, C. Berg, Can State Aid Control Learn from Antitrust? The Need for a Greater Role for Competition Analysis under the State Aid Rules, [w:] A. Biondi, P. Eeckhout, J. Flynn (red.), The Law of State Aid in the European Union, Oxford University Press, Oxford 2005, s. 41 i n.

${ }^{7}$ L. Hancher, Towards an Economic Analysis of State Aids, „European State Aid Quarterly” 2005 , no. 3, s. 431.

${ }^{8} \mathrm{Na}$ temat reformy wspólnotowego prawa pomocy publicznej zob. programowe wystąpienie N. Kroes, Reforming Europe's State Aid Regime: an Action Plan for Change, „European State Aid Quarterly” 2005, no. 3, s. 387 i n. 
Po zidentyfikowaniu tych wyjątków możliwe stanie się wskazanie podstaw ekonomicznych prawa pomocy publicznej. W możliwie szerokim zakresie zostanie uwzględnione orzecznictwo Komisji, ukazujące praktyczny wymiar omawianych zagadnień. Należy zwrócić uwagę na fakt, że w pracy nie odróżnia się, zasadniczo, europejskiego i krajowego prawa pomocy publicznej, wychodząc z założenia, że po 1 maja 2004 roku podział taki stracił wcześniejsze znaczenie, przynajmniej jeżeli chodzi o źródła prawa oraz podstawowe konstrukcje i rozwiązania. W jednym miejscu jednakże odstępuje się od tego założenia, w celu wskazania dodatkowych podstaw ekonomicznych europejskiego prawa pomocy publicznej. Należy podkreślić, że ramy artykułu uniemożliwiają wyczerpanie tematu i szczegółowe omówienie wszystkich kwestii związanych ze wskazanym wyżej przedmiotem wykładu, stąd wiele problemów zostanie jedynie zasygnalizowanych.

\section{POMOC PUBLICZNA W PIERWOTNYM PRAWIE EUROPEJSKIM}

Przystąpienie Polski do Unii Europejskiej spowodowało szereg istotnych zmian $\mathrm{w}$ polskim ustawodawstwie. $\mathrm{W}$ przypadku prawa pomocy publicznej zmiany te są zasadnicze. Od 1 maja 2004 roku podstawowe regulacje prawne z zakresu pomocy publicznej są uchwalane na poziomie europejskim, a system ich egzekwowania jest scentralizowany. Podstawy prawne europejskiego systemu kontroli udzielania pomocy publicznej zawarte są przede wszystkim w prawie pierwotnym. Najistotniejsze są w tym zakresie przepisy TFUE. Mniejsze znaczenie przypisać należy pozostałym dwóm traktatom ustanawiającym dwie kolejne Wspólnoty Europejskie ${ }^{9}$, tym bardziej że traktat paryski wygasł 23 lipca 2002 roku. Należy jednak wskazać, że zawierały one przepisy dotyczące pomocy publicznej, które warto w tym miejscu przypomnieć. Zgodnie z art. 4 lit. c traktatu paryskiego wprowadzony został całkowity zakaz udzielania jakiejkolwiek pomocy przez państwo dla przedsiębiorstw z sektora węgla i stali. Co więcej, zakaz ten był bezwzględny, tzn. nie przewidziano możliwości dokonywania indywidualnych wyłączeń. $Z$ biegiem czasu zakaz zawarty w traktacie paryskim był relatywizowany, w szczególności poprzez ekstensywną interpretację prawa pierwotnego. Natomiast Traktat EURATOM nie zawierał wprost przepisów o pomocy publicznej dla sektora energii atomowej. W dalszej części artykułu omawiane będą przepisy TFUE oraz prawa wtórnego, które mają podstawowe znaczenie dla systemu nadzoru pomocy publicznej.

${ }^{9}$ Traktat ustanawiający EURATOM podpisany w Rzymie 25 marca 1957 r. oraz Traktat ustanawiający Europejską Wspólnotę Węgla i Stali podpisany w Paryżu 18 kwietnia 1951 r. 


\section{POJĘCIE POMOCY PUBLICZNEJ}

Jak wskazano wyżej, dla prawa pomocy publicznej podstawowe znaczenie mają przepisy TFUE. W Traktacie pojęcie pomocy publicznej pojawia się kilkakrotnie, brakuje jednak legalnej definicji tego pojęcia. Dlatego jest ono rekonstruowane na podstawie interpretacji art. 107 ust. 1 TFUE. Przepis ten wprowadza domniemanie niezgodności ze wspólnym rynkiem pomocy publicznej udzielanej przez państwa członkowskie i wprowadza generalny zakaz jej udzielenia. Zakaz ten jest relatywizowany w ustępach 2 i 3 tego przepisu. Wykładnia art. 107TFUE prowadzi do wniosku, że pomocą publiczną jest:

1) pomoc nieobjęta jednym $z$ wyjątków zawartych $w$ Traktacie;

2) udzielana przez państwo lub ze środków publicznych;

3) mająca charakter selektywny (specyficzny), tzn. uprzywilejowująca niektórych przedsiębiorców lub produkcję niektórych towarów;

4) zakłócająca konkurencję;

5) wpływająca na handel między państwami członkowskimi ${ }^{10}$.

Działalność władz publicznych, posiadająca ww. cechy, jest pomocą publiczną i jako taka, na mocy art. 107 ust. 1 TFUE, jest zasadniczo zabroniona. Należy jednak wspomnieć, że art. 107 w ustępach 2 i 3 zawiera wyliczenie pewnych rodzajów pomocy, która jest lub może być uznana za zgodną ze wspólnym rynkiem. Również art. 109 TFUE zawiera delegację dla Rady do wydawania rozporządzeń wyłączających niektóre rodzaje pomocy spod generalnego zakazu z art. 107 ust. 1 . Rada skorzystała wielokrotnie $\mathrm{z}$ tego upoważnienia, wydając rozporządzenia wyłączające. Należy również wskazać, że uzupełnieniem tych aktów normatywnych są różnego rodzaju akty interpretacji prawa, w postaci wydawanych przez Komisję wytycznych (ang. guidelines) czy obwieszczeń (ang. notices) ${ }^{11}$, określanych zbiorczo mianem miękkiego prawa ${ }^{12}$ (ang. soft law). Wydawanie tych interpretacji służy zwiększeniu pewności prawnej po stronie przedsiębiorców oraz stanowi charakterystyczny element wspólnotowego systemu prawa konkurencji ${ }^{13}$.

${ }^{10}$ R. D'Sa, European Community law on state aid, Sweet and Maxwell, London 1998, s. 55.

${ }^{11}$ Wszystkie przepisy oraz akty prawa miękkiego dotyczące wspólnotowego prawa pomocy publicznej zawiera kompilacja przygotowana przez Komisję, która dostępna jest na stronie http:// ec.europa.eu/competition/state_aid/legislation/compilation/index_en.html (30.03.2009).

${ }^{12} \mathrm{Na}$ temat soft law zob. A. Jurcewicz, Soft law w prawie Wspólnot Europejskich, „Przegląd Legislacyjny” 1997, nr 4; M. Stępień, Zagadnienie soft law w prawie europejskim, AUWr., „Przegląd Prawa i Administracji” 2005, nr 66, a także L. Senden, Soft Law in European Community Law, Hart Publishing, Oxford 2004, czy U. Mörth (red.), Soft Law In Governance And Regulation. An Interdisciplinary Analysis, Edward Elgar Publishing, Cheltenham 2004.

${ }^{13}$ M. Cini, From soft law to hard law? Discretion and rule-making in the Commission's state aid regime, EUI, Florence 2000, s. 12 i n. 


\section{WYJĄTKI OD ZAKAZU UDZIELANIA POMOCY PUBLICZNEJ}

W celu określenia ekonomicznych podstaw prawa pomocy publicznej należy prześledzić, jakiego rodzaju pomoc publiczna uznawana jest za zgodną ze wspólnym rynkiem, stanowiąc tym samym wyjątek od generalnego zakazu. Art. 107 ust. 2 TFUE za zgodne $z$ rynkiem wewnętrznym uznaje następujące rodzaje pomocy publicznej: 1) pomoc o charakterze socjalnym przyznawaną indywidualnym konsumentom pod warunkiem, że jest przyznawana bez dyskryminacji związanej z pochodzeniem produktów, 2) pomoc mającą na celu naprawienie szkód spowodowanych klęskami żywiołowymi lub innymi zdarzeniami nadzwyczajnymi, 3) pomoc przyznawaną gospodarce niektórych regionów Republiki Federalnej Niemiec dotkniętych podziałem Niemiec, w zakresie, w jakim jest niezbędna do skompensowania niekorzystnych skutków gospodarczych spowodowanych tym podziałem. Pomoc taka jest dopuszczalna i uznawana a priori za zgodną ze wspólnym rynkiem.

Ponadto, zgodnie $z$ art. 107 ust. 3 TFUE, za zgodną z rynkiem wewnętrznym może zostać uznana: 1) pomoc przeznaczona na sprzyjanie rozwojowi gospodarczemu regionów, w których poziom życia jest nienormalnie niski, lub regionów, w których istnieje poważny stan niedostatecznego zatrudnienia; 2) pomoc przeznaczona na wspieranie realizacji ważnych projektów stanowiących przedmiot wspólnego europejskiego zainteresowania lub mająca na celu zaradzenie poważnym zaburzeniom w gospodarce państwa członkowskiego; 3) pomoc przeznaczona na ułatwianie rozwoju niektórych działań gospodarczych lub niektórych regionów gospodarczych, o ile nie zmienia warunków wymiany handlowej w zakresie sprzecznym ze wspólnym interesem; 4) pomoc przeznaczona na wspieranie kultury i zachowanie dziedzictwa kulturowego, o ile nie zmienia warunków wymiany handlowej i konkurencji we Wspólnocie w zakresie sprzecznym ze wspólnym interesem; 5) inne kategorie pomocy, jakie Rada może określić decyzją, stanowiąc większością kwalifikowaną, na wniosek Komisji.

Wykonując powyższe upoważnienie, Rada wydała Rozporządzenie nr 994/98 z dn. 7 maja 1998 r. dotyczące stosowania art. 92 i 93 Traktatu ustanawiającego Wspólnotę Europejską do niektórych kategorii horyzontalnej pomocy państwa ${ }^{14}$ stanowiące dla Komisji podstawę wydawania dalszych przepisów określających warunki przyznawania pomocy publicznej. Najważniejszym aktem wydanym przez Komisję, tworzącym bazę dla systemu wyłączania określonych form pomocy publicznej spod generalnego zakazu art. 107 TFUE, jest Rozporządzenie Komisji nr 800/2008 z dn. 6 sierpnia 2008 r. uznające niektóre rodzaje pomocy za zgodne

\footnotetext{
${ }^{14}$ Dz. U. WE L 142 z 14 maja 1998 r.
} 
ze wspólnym rynkiem w zastosowaniu art. 97 i 98 Traktatu ${ }^{15}$. Rozporządzenie to ma kluczowe znaczenie i stanowi pewien przełom w historii wspólnotowych regulacji z tego zakresu, albowiem kodyfikuje dużą część dotychczasowego ustawodawstwa wspólnotowego w dziedzinie pomocy publicznej. Zawiera ono zarówno zasady i definicje ogólne, mające zastosowanie do wszystkich rodzajów pomocy, jak i przepisy szczegółowe regulujące poszczególne rodzaje pomocy publicznej.

Tradycyjnie możemy wyróżnić następujące rodzaje pomocy publicznej: regionalną, sektorową i horyzontalną. Każdy z tych rodzajów pomocy ma swoje własne cele i zasady przyznawania. Pomoc regionalna przeznaczona jest na wyrównywanie poziomu gospodarczego regionów państw członkowskich UE. Udzielana jest na podstawie art. 107 ust. 3 (a) i (c) TFUE. Pomoc ta jest udzielana przedsiębiorstwom przede wszystkim na nowe inwestycje oraz na tworzenie miejsc pracy związanych $z$ tymi inwestycjami. Podstawowe znaczenie dla przyznawania pomocy regionalnej mają dwa akty: Wytyczne w sprawie krajowej pomocy regionalnej na lata 2007-2013 ${ }^{16}$ oraz Rozporządzenie Komisji (WE) nr 1628/2006 z dnia 24 października 2006 r. w sprawie stosowania art. 107 i 108 Traktatu w odniesieniu do regionalnej pomocy inwestycyjnej ${ }^{17}$. Pomoc sektorowa udzielana jest sektorom gospodarki, które napotykają trudności gospodarcze. Ukierunkowanie tej pomocy na dany sektor może mieć dwojaki cel: 1) ochronny - pomoc przeznaczona jest na restrukturyzację lub utrzymanie sektora przez ograniczenie przyrostu produkcji, 2) podażowy - pomoc udzielana jest w sytuacji, kiedy dany sektor nie jest w stanie poradzić sobie, opierając się na własnych środkach, $\mathrm{z}$ rosnącym popytem na produkty i konieczne jest zwiększenie sprzedaży. Pomoc horyzontalna zwana jest także pomocą ogólną lub pomocą niezależną od rodzaju przemysłu $(\text { cross-industry })^{18}$. Jak wskazują te określenia, jej beneficjentami mogą być przedsiębiorstwa niezależnie od tego, w jakiej gałęzi przemysłu czy też w jakim regionie prowadzą swoją działalność. Najważniejszymi rodzajami pomocy horyzontalnej są: 1) pomoc dla małych i średnich przedsiębiorstw, 2) pomoc na badania i rozwój, 3) pomoc przeznaczona na ochronę środowiska naturalnego, 4) pomoc na szkolenia, 5) pomoc na zatrudnienie, 6) pomoc na ratowanie i restrukturyzację przedsiębiorstw znajdujących się w trudnej sytuacji ${ }^{19}$.

${ }^{15}$ Dz. U. WE L 214 z 9 sierpnia 2008 r.

${ }^{16}$ Dz. U. WE C 54 z 4 marca 2006 r.

${ }^{17}$ Dz. U. WE L 302 z 1 listopada 2006 r.

${ }^{18}$ R. D’Sa, European Community..., s. 247.

${ }^{19}$ Można się spotkać w literaturze z zaliczeniem pomocy regionalnej do pomocy horyzontalnej - zob. L. Hancher, T. Ottervanger, P. J. Slot, E.C. State Aids, Sweet and Maxwell, London 1999, s. 278. Jednakże ze względu na daleko posuniętą specyfikę pomocy regionalnej pogląd ten nie wydaje się słuszny. 


\section{ZAWODNOŚCI RYNKU JAKO EKONOMICZNE PODSTAWY PRAWA POMOCY PUBLICZNEJ}

Istnienie pomocy publicznej w rozwiniętej gospodarce wolnorynkowej może nie wydawać się takie oczywiste. Rolą państwa w takim systemie nie jest przecież udzielanie wsparcia przedsiębiorcom, którzy powinni samodzielnie funkcjonować, a mechanizm konkurencji winien weryfikować ich zdolność do przetrwania i prowadzenia działalności gospodarczej. Okazuje się jednak, że takie podejście nie musi być zasadne w każdej sytuacji. Zgodnie z pierwszym założeniem ekonomii dobrobytu każda równowaga konkurencyjna, czyli równowaga kształtująca się na wolnych, niebędących przedmiotem jakiejkolwiek interwencji zewnętrznej np. państwa, warunkach, jest efektywna w rozumieniu Pareto ${ }^{20}$. O efektywnej alokacji w rozumieniu Pareto mówi się wtedy, kiedy nie ma możliwości poprawy sytuacji wszystkich osób zaangażowanych w proces wymiany albo też nie można poprawić sytuacji choćby jednej z tych osób, bez pogarszania jednocześnie sytuacji kogoś innego ${ }^{21}$. Skoro więc mechanizm wolnego rynku zapewnia najefektywniejszą alokację środków produkcji oraz maksymalizuje społeczny dobrobyt, to interwencja ze strony państwa może przyczynić się tylko do zniekształcenia tego sprawnego mechanizmu. Jednakże należy wskazać, że rynek jest efektywny tylko w sytuacji, gdy spełnione są określone warunki i dlatego można wskazać sytuacje, kiedy ten sprawny mechanizm nie funkcjonuje w sposób prawidłowy, co jest wynikiem istnienia sytuacji, określanych zbiorczo mianem „zawodności rynku”22 (ang. market failures). Zawodność rynku występuje wtedy, kiedy równowaga wolnokonkurencyjna nie prowadzi do efektywnej alokacji zasobów. Występująca niesprawność rynku uniemożliwia więc działanie „niewidzialnej ręki” rynku i prowadzi do nieefektywnej alokacji zasobów ${ }^{23}$. Istnienie tych zawodności uzasadnia interwencję państwa, które przy użyciu środków publicznych może niwelować negatywne efekty istniejących niesprawności rynku.

W dziedzinie prawa pomocy publicznej najczęściej możemy się spotkać z następującymi formami zawodności rynku:

Efekty zewnętrzne - to sytuacje, kiedy decyzja rynkowa jednego uczestnika rynku wpływa bezpośrednio na decyzje innych uczestników rynku, przy czym wpływ ten nie jest zamierzony. Są to więc koszty lub korzyści osób trzecich, niepodlegające rekompensacie i powstałe wskutek produkcji lub konsumpcji drugiego podmiotu, który nie ponosi kosztów lub korzyści związanych z tymi

${ }^{20}$ H. R. Varian, Mikroekonomia. Kurs średni-ujęcie nowoczesne, Wydawnictwo Naukowe PWN, Warszawa 2005, s. 547.

${ }^{21}$ Ibidem, s. 530.

${ }^{22}$ J. E. Stiglitz, Ekonomia sektora publicznego, PWE, Warszawa 2004, s. 91 i n.

${ }^{23}$ D. Begg, S. Fischer, R. Dornbusch, Mikroekonomia, PWE, Warszawa 2003, s. 442. 
działaniami ${ }^{24}$. Efekty zewnętrzne mogą być negatywne, np. w wyniku używania technologii oddziałującej negatywnie na środowisko naturalne, lub pozytywne, np. w przypadku działalności R\&D. W rozważaniach z zakresu prawa pomocy publicznej efekty zewnętrzne zajmują tradycyjnie najwięcej miejsca ${ }^{25}$.

Dobra publiczne - to produkty lub usługi, które mają jednocześnie dwie specyficzne cechy: każdy może $\mathrm{z}$ nich korzystać oraz konsumpcja tych dóbr przez jedną osobę nie umniejsza ich dostępności dla innych zainteresowanych ${ }^{26}$. Przykładami dóbr publicznych są: latarnie morskie, oświetlenie uliczne, bezpieczeństwo publiczne czy publiczne radio i telewizja. Zapewnienie ich dostępności na poziomie zaspokajającym społeczne potrzeby nie musi i często nie jest ekonomicznie opłacalne dla prywatnych przedsiębiorstw.

Dobra społecznie pożądane (ang. merit goods) - to dobra, o których społeczeństwo sądzi, że każdy powinien je mieć bez względu na to, czy jest nimi zainteresowany ${ }^{27}$. Dobra te charakteryzują się tym, że pozostawienie ich konsumpcji wyłącznie swobodnej grze rynkowej spowoduje jej spadek oraz ograniczenie ich dostępności poniżej poziomu uważanego za pożądany, z punktu widzenia interesu publicznego. Konsumenci mogą nie doceniać wartości tych dóbr, co skutkować może spadkiem popytu na nie w sytuacji, gdy ich cena będzie ceną rynkową ${ }^{28}$. W tej sytuacji interwencja rządu jest konieczna, aby zachęcić, albo wręcz zobowiązać konsumentów do korzystania z tych dóbr. Przykładami takich dóbr są: edukacja, opieka zdrowotna czy dostępność dóbr kultury i sztuki.

Korzyści skali - rynki charakteryzujące się stałym wzrostem korzyści skali nie są doskonale konkurencyjne. Korzyści skali wynikają ze spadających kosztów średnich, względnie rosnących przychodów ze skali ${ }^{29}$. Osiąganie takich korzyści możliwe jest przy strukturze monopolistycznej lub oligopolistycznej, kiedy produkcja zależy od jednego lub kilku producentów, prowadząc do tego, że cena kształtuje się powyżej kosztu krańcowego, a produkcja poniżej społecznego optimum.

Siła rynkowa - istnienie przedsiębiorstwa dysponującego istotną siłą rynkową, w skrajnym wypadku - monopolisty, może prowadzić do istotnych nieefektywności rynkowych. Warto zauważyć, że państwo swoim działaniem może wspierać

${ }^{24}$ E. Czarny, Mikroekonomia, PWE, Warszawa 2006, s. 349.

${ }^{25}$ R. Meiklejohn, The economics of State Aid, [w:] State aid and the single market, European Economy 3, Reports and Studies, no. 3, European Commission, Brussels 1999, s. 28.

${ }^{26}$ Z. Wiszniewski, Wybrane zagadnienia teorii przedsiębiorstwa, [w:] M. Bednarski i J. Wilkin (red.), Ekonomia dla prawników i nie tylko, wyd. 3, LexisNexis, Warszawa 2006, s. 108.

${ }^{27}$ D. Begg, S. Fischer, R. Dornbusch, op. cit., s. 471.

${ }^{28}$ R. Meiklejohn, op. cit., s. 26.

${ }^{29}$ Ch. Bongard, D. Moeller, A. Raimann, N. Szadkowski, U. Dubjeko, Instrumenty ekonomiczne w prawie konkurencji, UOKiK, Bonn-Warszawa 2007, s. 51. 
zarówno istnienie i powstanie takiego przedsiębiorstwa, jak i spowodować jego osłabienie np. wskutek ułatwienia wejścia na rynek innym przedsiębiorcom ${ }^{30}$.

Asymetria informacji oraz rynki nieistniejące (ang. missing markets) - pomiędzy popytową i podażową stroną rynku często występuje asymetria informacji, która prowadzi do tego, że dany rynek nie może się rozwinąć, np. wskutek tego, że banki nie rozpoznały, że nowa technologia jest lepsza od już istniejącej i warto w nią zainwestować ${ }^{31}$.

Problem koordynacji - opisuje on zawodność rynku skutkującą nieefektywnym funkcjonowaniem rynku, ze względu na brak koordynacji pomiędzy działaniami jego uczestników. W szczególności problem ten objawi się w przypadku braku wspólnych norm lub standardów prowadzenia określonej działalności ${ }^{32}$.

Subsydiowanie zagranicznych przedsiębiorców - tradycyjnym elementem polityki gospodarczej państw jest poprawa konkurencyjności krajowego przemysłu, poprzez różne formy subsydiowania działalności eksportowej krajowych przedsiębiorstw. Tego rodzaju zachowanie państwa może być jego wyłączną inicjatywą, może natomiast być też formą obrony przed podobną polityką innych państw. W chwili obecnej, wobec liberalizacji światowej wymiany handlowej, pod egidą Światowej Organizacji Handlu zakres subsydiowania podmiotów krajowych ulega obniżeniu ${ }^{33}$.

\section{KONCEPCJE SŁUSZNOŚCI/SPRAWIEDLIWOŚCI JAKO EKONOMICZNE PODSTAWY PRAWA POMOCY PUBLICZNEJ}

Analiza wyjątków od zakazu udzielania pomocy publicznej daje podstawę do stwierdzenia, że oprócz interwencji państwowej skierowanej przeciwko istniejącym zawodnościom rynku, pomoc ta może być także motywowana celami słuszności/sprawiedliwości (ang. equity). Przykładami takiej pomocy może być pomoc na rzecz kultowej różnorodności czy pomoc na rzecz spójności i pomoc regionalna.

Jak wskazuje się w teorii ekonomii, interwencja państwa oparta na przesłankach słuszności nie musi prowadzić do efektów odmiennych od pomocy opartej na przesłankach efektywnościowych ${ }^{34}$. Realizując zadania z zakresu polityki re-

${ }^{30}$ H. W. Friederiszick, L.-H. Roeller, V. Verouden, European State Aid Control: An Economic Framework, [w:] P. Buccirossi (red.), Handbook of Antitrust Economics, MIT Press, London 2007, s. 634.

${ }^{31}$ Więcej A. Przeworski, States and Markets. Primer in Political Economy, Cambridge University Press, Cambridge 2003, s. 46 i n.

${ }^{32}$ H. W. Friederiszick, L.-H. Roeller, V. Verouden, European State Aid Control..., s. 633 i 634.

${ }^{33}$ R. Meiklejohn, op. cit., s. 31.

${ }^{34}$ J. E. Stiglitz, op. cit., s. 319. 
gionalnej, przyznawana pomoc publiczna może odnieść pozytywne skutki zarówno dla odbiorców pomocy, jak i dla całego otoczenia konkurencyjnego w danym regionie ${ }^{35}$. Przykładem może być pomoc publiczna dla przedsięwzięć związanych $\mathrm{z}$ budownictwem socjalnym. W tym przypadku podstawą przyznawania pomocy jest zasada solidaryzmu społecznego będąca wyrazem przekonania społecznego o konieczności pomagania tym członkom społeczeństwa, których nie stać na zapewnienie sobie mieszkania na warunkach rynkowych ${ }^{36}$. W innej sprawie Komisja zaakceptowała program pomocy publicznej na szkolenia pracowników nowo tworzonej fabryki samochodów w Portugalii w regionie o kiepskiej sytuacji gospodarczej ${ }^{37}$. Głównym argumentem w tym przypadku była chęć zapewnienia spójności pomiędzy regionami oraz pomoc osobom zamieszkującym region o najgorszych parametrach ekonomicznych.

Przesłanki różnorodności kulturowej oraz pluralizmu w mediach stanowią także dobrą ilustrację praktycznego wdrażania celów słusznościowych w prawie pomocy publicznej. Przykładem może być pomoc udzielana przez rząd Finlandii lokalnej prasie wydawanej w języku mniejszości narodowej, tj. w języku szwedzkim. Komisja uznała, że choć wsparcie dla szwedzkojęzycznych mediów może pogorszyć pozycję konkurencyjną mediów fińskojęzycznych, to jednak pogorszenie to będzie ograniczone $\mathrm{w}$ skutkach, korzyści zaś związane $\mathrm{z}$ promocją pluralizmu medialnego oraz wielojęzyczności w Finlandii będą przeważające ${ }^{38}$. Podobnie Komisja uznała, że pomoc dla baskijskich teatrów nie wpłynie na handel wewnątrzwspólnotowy, a niewątpliwie przyczyni się do wsparcia kulturalnego mniejszości baskijskiej w Hiszpanii ${ }^{39}$. W innej sprawie Komisja potwierdziła, że dopuszczalne jest wsparcie przez władze holenderskie istnienia muzeum lotnictwa, gdyż bez takiego wsparcia muzeum nigdy by nie powstało ${ }^{40}$.

W doktrynie zwraca się uwagę na to, że cele słusznościowe oraz efektywnościowe nie muszą być sobie przeciwstawne. Poszczególne środki pomocowe moga realizować zadania z obydwu grup ${ }^{41}$. Przykładowo wsparcie dla istnienia placówek muzealnych realizuje zarówno słusznościowy argument o konieczności ochrony dziedzictwa kulturowego, jak i związany jest $\mathrm{z}$ jedną form zawodności rynku, jaką jest potrzeba zapewnienia istnienia dóbr publicznych w postaci muzeów.

${ }^{35}$ H. W. Friederiszick, L.-H. Roeller, V. Verouden, EC Sate Aid Control: An Economic Perspective, [w:] M. Sanchez Rydelski (red.), The EC State Aid Regime. Distortive Effects of State Aid on Competition and Trade, Cameron May, London 2008, s. 156.

${ }^{36}$ Więcej A. Bartosch, Social Housing and European State Aid Control, „European Competition Law Review” 2007, no. 10, s. 564 i n.

${ }^{37}$ Sprawa N 635/2005, Webasto.

${ }^{38}$ Sprawa N 537/2007, Aid for Finish newspapers.

${ }^{39}$ Sprawa N 257/2007, Spain - Subsidies for theatre production in the Basque country.

${ }^{40}$ Sprawa N 221/2003, Dutch aviation museum.

${ }^{41}$ H. W. Friederiszick, L.-H. Roeller, V. Verouden, EC Sate Aid Control..., s. 157-158. 


\section{EKONOMICZNE PODSTAWY EUROPEJSKIEGO PRAWA POMOCY PUBLICZNEJ}

Dotychczasowa analiza odwoływała się w dużym stopniu do ustaleń ekonomii dobrobytu i w gruncie rzeczy można ją odnieść do dowolnego państwa na świecie. Co istotne, również w przypadku takich organizacji jak Unia Europejska ustalenia te są przekonujące. Jednakże istnienie wspólnotowego prawa pomocy publicznej, ze względu na szczególny charakter UE, zyskuje swoje dodatkowe ekonomiczne uzasadnienie. Należy to traktować jako uzupełnienie wcześniejszych ustaleń dotyczących ekonomicznych podstaw prawa pomocy publicznej. Od 1 maja 2004 roku, zasadniczo, każda nowa forma pomocy publicznej, czy to w postaci programu pomocowego, czy pomocy indywidualnej, musi zostać notyfikowana Komisji, która pełni funkcję głównego organu decyzyjnego w zakresie pomocy publicznej w Unii Europejskiej. Mimo tej istotnej roli Komisji krajowe organy administracji publicznej wciąż pozostają jej ważnym partnerem w zakresie realizacji polityki konkurencji (choć rola ich jest mniejsza niż np. w przypadku stosowania wspólnotowych przepisów antymonopolowych ${ }^{42}$ ). Warto w tym miejscu podkreślić, że zmiana w systemie pomocy publicznej po przystąpieniu Polski do UE miała charakter nie tylko formalny (przeobrażenia w systemie źródeł prawa i sferze instytucjonalnej), ale zmianie uległy także ekonomiczne podstawy sytemu pomocy publicznej. O ile w przypadku krajowego systemu pomocy publicznej przedmiotem regulacji jest zachowanie prywatnych uczestników rynku, a interwencja państwa uzasadniana jest poprzez porównanie kosztów społecznych i kosztów prywatnych braku udzielenia pomocy publicznej, o tyle w przypadku europejskiego systemu pomocy publicznej przedmiotem regulacji jest przede wszystkim zachowanie się władz publicznych krajów członkowskich $\mathrm{UE}^{43}$, których interwencja na rynku krajowym może powodować zakłócenia konkurencji na wspólnym rynku. To powoduje, że do pewnego stopnia odmienne są ekonomiczne podstawy krajowego i wspólnotowego systemu pomocy publicznej ${ }^{44}$ i różne jest uzasadnienie ich ist-

${ }^{42}$ Zob. Rozporządzenie Rady nr 1/2003 z dn. 16 grudnia 2002 r. w sprawie wprowadzenia w życie reguł konkurencji ustanowionych w art. 81 i 82 Traktatu, Dz. U. UE L 001 z 4 stycznia $2003 \mathrm{r}$.

${ }^{43}$ Stwierdzenie to jest pewnym uproszczeniem, ze względu na bardzo szerokie rozumienie pojęć „państwa” i „środków publicznych” w prawie pomocy publicznej. Zob. S. Dudzik, Pomoc pañstwa dla przedsiębiorstw publicznych w prawie Wspólnoty Europejskiej, Zakamycze, Kraków 2002, s. 97 i n.

${ }^{44}$ Wyrazem tego może być pewna subtelna zmiana w używanej nomenklaturze. W przypadku krajowych regulacji właściwsze byłoby mówienie o systemie pomocy publicznej, w przypadku zaś regulacji wspólnotowej lepsze byłoby określenie system kontroli udzielania pomocy publicznej. 
nienia. W celu uzasadnienia istnienia ponadnarodowego, wspólnotowego systemu kontroli pomocy publicznej wskazuje się na występowanie trzech okoliczności ${ }^{45}$ :

Ponadnarodowe efekty zewnętrzne - objawiają się w tym, że udzielenie pomocy przez jedno państwo krajowemu przedsiębiorcy może wywoływać efekty uboczne w innych krajach europejskich. Efekty te mogą mieć charakter pozytywny, ale często mają charakter negatywny. Negatywne ponadnarodowe efekty zewnętrzne są związane $\mathrm{z}$ polityką ochrony własnego rynku, własnych przedsiębiorców czy konsumentów. Stanowią więc wyraz protekcjonizmu czy nawet nacjonalizmu gospodarczego ${ }^{46}$. Tradycyjnie tego rodzaju efekty związane są ze stosowaniem przez państwa różnorodnych form wspierania eksportu czy też utrudniania importu. Jednak w sytuacji zintegrowanych i powiązanych ściśle gospodarek państw członkowskich UE udzielanie pomocy publicznej, nawet w postaci subsydiów eksportowych dla towarów lub usług wywożonych poza UE, w jednym kraju może potencjalnie wpływać negatywnie na sytuację przedsiębiorców w innych krajach członkowskich.

Problem miękkiego budżetowania - sprowadza się do niekonsekwencji rządów krajowych, które w imię doraźnych celów mogą podejmować interwencję na rynkach narodowych. Przedsiębiorstwa wiedzą bowiem, że w przypadku sytuacji kryzysowych mogą wymusić na rządach udzielenie wsparcia publicznego. Prowadzi to do spadku zarówno efektywności, jak i dobrobytu społecznego. Organ ponadnarodowy, taki jak Komisja, może być mniej podatny na wpływy krajowych przedsiębiorców, będąc zobowiązany do stosowania jednolitej polityki w stosunku do wszystkich zainteresowanych stron. $Z$ drugiej jednak strony skuteczność działań Komisji nie zawsze może być najwyższa, co może być wynikiem braku dostatecznej informacji na temat wszystkich krajowych aspektów danego środka pomocowego ${ }^{47}$. W tym kontekście można stwierdzić, że obecna akceptacja Komisji dla pomocy publicznej w sektorze finansowym stanowi odejście od zarysowanych reguł, a uzasadnienia odwołujące się do zawodności rynku stanowią jedynie alibi dla czysto politycznych decyzji poszczególnych krajów członkowskich $\mathrm{UE}^{48}$.

Przesłanka wspólnego rynku - istnienie wspólnego rynku to jedna z podstaw funkcjonowania Unii Europejskiej. Integracja rynków krajowych i znoszenie

${ }^{45}$ H. W. Friederiszick, L.-H. Roeller, V. Verouden, European State Aid Control..., s. 638 i n.

${ }^{46}$ Ciekawym przykładem takiej polityki była próba uzależnienia pomocy Francji dla krajowych producentów samochodowych uzależniona od nieprzenoszenia produkcji do innych krajów członkowskich UE. Program ten spotkał się z krytyką Komisji i Francja musiała zmienić, przynajmniej formalnie, niektóre najbardziej kontrowersyjne elementy tego programu. $\mathrm{Na}$ ten temat zob. N. Tait, Brussels and France resolve dispute over car industry, http://www.ft.com/cms/s/0/ e42b2302-06cb-11de-ab0f-000077b07658.html (2.03.2009).

${ }^{47}$ H. W. Friederiszick, L.-H. Roeller, V. Verouden, European State Aid Control..., s. 639.

${ }^{48}$ Podobnie R. D'Sa, Instant State Aid Law In a Financial Crisis - A U - Turn?, „European State Aid Quarterly” 2009, no. 2, s. 144. 
barier narodowych było od początku jednym z podstawowych celów wspólnotowej polityki konkurencji ${ }^{49}$. W zintegrowanej Europie wspólny rynek, poprzez zapewnienie istnienia efektywnej konkurencji oraz uzyskiwanie korzyści skali, stymuluje wzrost gospodarczy. Interwencje rządów krajowych osłabiają ten cel i godzą $\mathrm{w}$ interes ponadnarodowy, zakłócając tym samym swobodny przepływ kapitału, towarów czy usług.

\section{ZASTOSOWANIE USTALEŃ TEORETYCZNYCH W PRAKTYCE}

Wskazane wyżej ekonomiczne uzasadnienie prawa pomocy publicznej nabiera istotnego znaczenia w kontekście podjętej przez Komisję reformy systemu pomocy publicznej określanej zbiorczo SAAP. Plan ten realizowany pod hasłem Less and Better Targeted Aid ${ }^{50}$ miał na celu modernizację zasad przyznawania pomocy publicznej w Europie. Jednym z centralnych założeń SAAP jest wprowadzenie tzw. testu bilansującego. Celem testu jest ocena, na ile zaproponowana pomoc jest dopuszczalna, jako zgodna ze wspólnym rynkiem. W ramach testu bilansującego badane jest: 1) czy przyjęty cel pomocy służy wyeliminowaniu zawodności rynku lub też służy innemu celowi leżącemu we wspólnym interesie UE (np. cel społeczny, regionalny, gospodarczy czy też kulturowy), 2) czy pomoc państwa jest stosownym narzędziem rozwiązania problemu w porównaniu $z$ innymi dostępnymi środkami, oraz 3) czy pomoc powoduje powstanie pożądanych zachęt i czy jej wysokość jest odpowiednia ${ }^{51}$. Jak widać, jednym z kluczowych elementów testu bilansującego jest analiza zawodności rynkowych, takich jak efekty zewnętrzne, niepełne informacje lub problemy z koordynacją, które mogą być przyczynami tego, że rynki są nieefektywne. Powoduje to, że władze publiczne zamierzające przyznać pomoc publiczną muszą wyraźnie wskazać i zanalizować zawodności rynku, co ma pomóc Komisji w lepszej ocenie tego, czy pomoc publiczną można uzasadnić i zaakceptować, czy jest ona najwłaściwszym rozwiązaniem oraz jak należy ją wdrażać, aby osiągnąć pożądany cel, nie zakłócając konkurencji i handlu $\mathrm{w}$ stopniu niezgodnym ze wspólnym interesem ${ }^{52}$. Wprowadzenie testu bilansującego odpowiada w istotnym stopniu postulatom wysuwanym w literaturze ${ }^{53}$.

${ }^{49}$ Bellamy \& Child, European Community law of competition, Oxford University Press, Oxford 2008, s. 40.

${ }^{50}$ SAAP, http://eur-lex.europa.eu/LexUriServ/LexUriServ.do?uri=CELEX:52005DC0107: EN:NOT (22.02.2009). Wobec skandalicznej jakości polskiego tłumaczenia tego dokumentu, wypaczającego jego sens, posługiwanie się tekstem angielskim jest niestety nieodzowne.

${ }^{51}$ SAAP, nb. 20.

${ }^{52}$ SAAP, nb. 23.

${ }^{53}$ Zob. R. Nitsche, P. Heidhues, Study on methods to analyse the impact of State aid on competition, „Economic Papers”, February 2006, no. 244, European Commission, Brussels. 
Rozwinięciem tego testu jest opublikowany w połowie 2009 roku dokument konsultacyjny Komisji, tj. Wspólne zasady ekonomicznej oceny zgodności pomocy państwa ze wspólnym rynkiem na mocy art. 107 ust. $3^{54}$. Celem tego dokumentu jest stworzenie bardziej szczegółowych wyjaśnień metod stosowanych przez Komisję przy sporządzaniu oceny $\mathrm{z}$ wykorzystaniem testu bilansującego.

Analizując najnowsze orzecznictwo Komisji, można wskazać już kilka spraw, w których Komisja zastosowała test bilansujący. Przykładem może być decyzja Komisji z dn. 21 lutego 2007 r. w sprawie NeoVal${ }^{55}$. Sprawa ta dotyczyła pomocy dla spółki zależnej Siemensa działającej we Francji, tj. NeoVal. Pomoc miała zostać ukierunkowana na wdrożenie programu rozwoju nowoczesnych pociągów miejskich (metra). Stworzenie nowych technologii wykorzystywanych w miejskim transporcie miało na celu zniwelowanie istniejących zawodności rynku, w szczególności w postaci efektów zewnętrznych. Nowe pociągi metra miały zużywać mniej energii, poprawiać jakość publicznego transportu, niwelować efekty miejskich korków. Ponadto projekt tworzony przez NeoVal mógł prowadzić do pozytywnych efektów zewnętrznych w postaci rozwoju nowej technologii, która mogła stać się udziałem innych przedsiębiorców. W innej decyzji Komisji z dnia 10 maja 2007 r. w sprawie $T V M S L^{56}$ wskazano na istnienie problemu koordynacji, jako zawodności rynku, jako jednego z głównych argumentów za przyznaniem pomocy. Pomoc publiczna w tej sprawie była ukierunkowana na rozwój technologii pozwalającej na połączenie sieci satelitarnej i naziemnej w celu dostarczania programów telewizyjnych użytkownikom telefonów komórkowych. Projekt ów nie byłby możliwy bez udziału w nim wielu podmiotów, na czele z Alcatel-Lucent, prowadzących działalność gospodarczą na różnych rynkach. Brak współpracy wielu partnerów powodowałby niską opłacalność przedsięwzięcia i wzrost kosztów. W kolejnej sprawie Komisja rozważyła występowanie asymetrii informacji jako zawodności rynku. W decyzji z dnia 10 lipca 2007 r. w sprawie Projet Bernin $2010^{57}$ Komisja nie przyjęła w pełni argumentacji opartej na istnieniu asymetrii informacji. Sprawa ta dotyczyła stworzenia projektu technologicznego zmierzającego do wynalezienia nowego materiału do produkcji komputerowych chipów. Rząd francuski wskazywał, że projekt jest dochodowy, ale w długim terminie, ze względu zaś na duże koszty początkowe i brak dochodowości w pierwszych latach

54 Dostępne na http://ec.europa.eu/competition/state_aid/reform/economic_assessment_ pl.pdf (13.08.2009).

${ }_{55}^{5}$ Sprawa N674/2006, Soutien de l'Agence de l'innovation industrielle en faveur du projet NeoVal.

${ }^{56}$ Sprawa N854/2006, Soutien de l'Agence de l'innovation industrielle en faveur du programme mobilisateur pour l'innovation industrielle TVMSL.

${ }^{57}$ Sprawa N887/2006, Projet Bernin 2010. 
nie będzie możliwe znalezienie finansowania zewnętrznego i projekt nie dojdzie do skutku.

\section{ZAKOŃCZENIE}

Istnienie różnych zawodności rynku może uzasadniać interwencję państwa i udzielenie pomocy publicznej. W praktyce, analizując konkretne formy pomocy, może okazać się, że brakuje jednak im obiektywnego uzasadnienia lub mają one charakter stricte polityczny i pozaekonomiczny. Pomoc publiczna udzielana, w sytuacji braku ekonomicznego uzasadnienia prowadzi do nieefektywnej alokacji środków i obniża dobrobyt społeczny. Prawo pomocy publicznej ma za zadanie zminimalizowanie tego rodzaju interwencji państwa i doprowadzenie do sytuacji, kiedy pomoc publiczna nie naruszy równowagi rynkowej. Należy podkreślić, że dokładna analiza wyżej przedstawionych zawodności rynku daje solidne podstawy do oceny, czy przyznawana pomoc publiczna wywrze pozytywne skutki rynkowe. Trzeba wszakże pamiętać, że jest to oczywiście jedynie potencjalna możliwość, gdyż zgodnie z testem bilansującym każdorazowo konieczne jest zbadanie, co kieruje władzami publicznymi udzielającymi pomocy publicznej i czy proponowane środki są najlepszym rozwiązaniem zidentyfikowanego problemu. Warte podkreślenia jest to, że zidentyfikowanie istnienia zawodności rynku nie oznacza, że pomoc publiczna stanowi rozwiązanie tego problemu, że rzeczywiście jest potrzebna i doprowadzi do zmiany zachowania przedsiębiorców i pozytywnych skutków rynkowych ${ }^{58}$. To także musi zostać udowodnione $\mathrm{w}$ ramach testu bilansującego.

Analiza ekonomicznego uzasadnienia przyznawanej pomocy publicznej jest jednym $z$ kluczowych elementów podjętej przez Komisję reformy systemu pomocy publicznej. Podobne zmiany były postulowane już od połowy lat 90 . ubiegłego wieku ${ }^{59}$. Zgodnie $\mathrm{z}$ założeniami tego planu wielkość pomocy publicznej winna być stopniowo zmniejszana, a kryteria jej przyznawania winny być zobiektywizowane i poparte ekonomiczną analizą wpływu pomocy na konkurencję na rynku wewnętrznym. Niestety należy zauważyć, że wobec kryzysu finansowego nie wszystkie z tych ambitnych założeń okazały się możliwe do spełnienia. Komisja zmuszona została do podjęcia wielu środków mających na celu stworzenie ram prawnych dla udzielania pomocy publicznej przedsiębiorstwom sektora finanso-

${ }^{58} \mathrm{Ph}$. Nicolaides, Incentive Effect: Is State Aid Necessary when Investment Is Unnecessary?, „European State Aid Quarterly" 2008, no. 2, s. 231.

${ }^{59} \mathrm{~S}$. Bishop, The European Commission's Policy Towards State Aid: A role for Rigorous Competitive Analysis, „European Competition Law Review” 1997, no. 2, s. 84 i n. 
wego ${ }^{60}$. Mimo to należy wskazać, że istotny postęp został dokonany, a ekonomiczna analiza w prawie pomocy publicznej stała się nieodzowna. I choć test bilansujący nie jest jeszcze narzędziem doskonałym ${ }^{61}$, to przyczyni się on niewątpliwie do racjonalizacji udzielania pomocy publicznej w krajach UE i oparcia jej na solidnych podstawach ekonomicznych, w szczególności poprzez analizę zawodności rynku.

\section{THE ECONOMIC BASIS OF STATE AID LAW}

SUMMARY

The paper addresses the issue of the economic basis of state aid law. Although the issue has been absent in the Polish legal literature there is a growing debate over the economization of state aid law in European jurisprudence. The increasing role of economic analysis in state aid cases is the result of the new Commission plan of modernization and limitation of state aid in Europe called Less and Better Targeted Aid. It has been argued that the economic basis of the state aid law are two economic concepts i.e. market failures and equity. The most important market failures are: externalities, public goods, merit goods, economies of scale, imperfect information and missing markets. Whenever it is possible reference to case law is made in order to present the application of economic theories in practice.

${ }^{60}$ Przegląd wszystkich działań Komisji w tym zakresie przedstawia R. Luja, State Aid and the Financial Crisis: Overview of the Crisis Framework, „European State Aid Quarterly” 2009, no. 2, s. 145 i n.

${ }^{61}$ Ch. Buelens, G. Garnier, R. Meiklejohn, M. Johnson, The economic analysis of state aid: Some open question, „European Economy. Economic Papers”, September 2007, no. 286, s. 4 i n. 